\title{
Learning strategies used by undergraduate and postgraduate students in hybrid courses in the area of health ${ }^{1}$
}

\author{
Henry Maia Peixoto ${ }^{2}$ \\ Mariana Maia Peixoto ${ }^{3}$ \\ Elioenai Dornelles Alves ${ }^{4}$
}

This study aimed to investigate the learning habits and strategies of undergraduate and postgraduate students matriculated in hybrid courses in the area of healthcare at a Brazilian university. 220 graduate students were invited to participate in the research, of whom $67.27 \%$ accepted. An exploratory methodology was utilized, which analyzed quantitative data collected by a structured instrument. A similarity may be observed between undergraduate and postgraduate students concerning the majority of education habits and learning strategies, such as the large proportion of those who read more than half of the course content and of those who preferred to study alone, as well as in the high use of the majority of strategies evaluated. It is concluded that both the groups present appropriate study habits and satisfactorily used the learning strategies investigated.

Descriptors: Education, Distance; Education, Higher; Learning.

\footnotetext{
${ }^{1}$ Paper extracted from Master's Thesis "Avaliação do Ensino da Promoção da Saúde em Disciplinas de Graduação e Pós-graduação da Área de Saúde na Universidade de Brasília", presented to Universidade de Brasília, Brasil.

2 Master's student, Universidade de Brasília, Brasil.

${ }^{3}$ Undergraduate student at the Computer Science Diploma Program, Universidade Federal da Paraíba, Brasil.

${ }^{4} \mathrm{PhD}$, Full Professor, Universidade de Brasília, Brasil.
} 


\title{
Estratégias de aprendizagem utilizadas por graduandos e pós-graduandos em disciplinas semipresenciais da área de saúde
}

Este estudo teve por objetivo investigar os hábitos e estratégias de aprendizagem de graduandos e pós-graduandos em uma universidade brasileira, matriculados em disciplinas semipresenciais da área de saúde. Foram convidados todos os 220 alunos concluintes, dos quais $67,27 \%$ aceitaram participar da pesquisa. Foi utilizada metodologia exploratória, que analisou dados quantitativos, coletados por um instrumento estruturado. Pôde-se observar semelhança entre graduandos e pós-graduandos quanto à maioria dos hábitos de ensino e estratégias de aprendizagem, assim como maior proporção daqueles que leram mais da metade do conteúdo, dos que preferem estudar sozinhos, além do elevado uso da maioria das estratégias avaliadas. Conclui-se que ambos os grupos apresentaram hábitos de estudo adequados e utilizaram satisfatoriamente as estratégias de aprendizagens investigadas.

Descritores: Educação a Distância; Educação Superior; Aprendizagem.

\section{Estrategias de aprendizaje utilizadas por estudiantes universitarios y de posgrado en asignaturas semi-presenciales en el área de la salud.}

\begin{abstract}
Este estudio tuvo como objetivo investigar los hábitos y las estrategias de aprendizaje de los estudiantes universitarios y de posgrado en una universidad brasileña, matriculados en las asignaturas semi-presenciales del área de la salud. Fueron invitados a todos los 220 estudiantes graduados, de los cuales 67,27\% aceptaron participar de la investigación. Se utilizó una metodología exploratoria, que analizó los datos cuantitativos recogidos por un instrumento estructurado. Se pudo observar una similitud entre los estudiantes universitarios y de posgrado acerca de los de la mayoría de los hábitos de enseñanza y estrategias de aprendizaje, así como una mayor proporción de los que leyeron más de la mitad del contenido, de los que prefieren estudiar solos, además de la elevada utilización por la mayoría, de las estrategias evaluadas. Llegamos a la conclusión de que ambos los grupos presentaron hábitos adecuados de estudio y se utilizaron de manera satisfactoria de las estrategias de aprendizaje investigadas.
\end{abstract}

Descriptores: Educación a Distancia; Educación Superior; Aprendizaje.

\section{Introduction}

Modern society has experienced deep transformations driven by the use of Information and Communication Technology (ICT), which challenges, and produces disturbance in, current educational practices and concepts, being geared to creating new forms of teaching and learning, adapted and potentialized by communications technology(1).

In this perspective, the widening of access to the Internet has exercised a fundamental role, by making possible the use of computational tools which incorporate didactic material, sound files, images and video - all interactively(2).

The educative process made possible by new technologies takes place in a virtual learning environment (VLE) which is part of cyberspace, covers instructional interfaces, and favors interaction between learners. It includes tools for independent action and offers resources for both individual and collective learning ${ }^{(3)}$.

Among the tools available, the following stand out: asynchronous communication tools (forums, email, blogs, message boards) and synchronous tools, such as chat; evaluation tools and collectively constructed ones (tests, works, wikis, glossaries); instructional tools (texts, activities, books, videos); opinion survey tools (surveys, questionnaires); and administrative tools (for student profiling, registering, issuing passwords, setting up groups, databases, configurations, class diaries, creation of attendance registers and creation of reports, graphics, and participation statistics) ${ }^{(4)}$.

In the face of all these possibilities, discussion has arisen in the health area about the capacity of distance 
education through ICT-assisted collective learning to encourage the adoption of study habits and learning strategies which might be capable of effecting critical and reflexive training, in view of the liberty the student has to organize his or her studies(5-6).

To this end, the Center for Distance Education, Health Promotion and Inclusive Projects (Núcleo por Estudos em Educação, Promoção da Saúde e Projetos Inclusivos) has been coordinating provision of undergraduate and postgraduate disciplines by the University of Brasilia (UnB) based on a standard model of electronic portfolios inserted into virtual learning environments, termed Moodlefolios, whose use has been as a collective meeting point which permits the registration of processes and products resulting from activities developed in the disciplines. The choice of the Moodle VLE is justified by the fact that it is a platform which offers virtual spaces which are ideal places for the students to get together, share, collaborate and learn together(4).

This new teaching dynamic shows its relevancy by allowing the insertion of the student in a new virtual reality, which by privileging interactive media and collaborative learning, enables learning(5). Nevertheless, the expansion of distance learning in health, both at undergraduate and postgraduate levels, has not been appropriately discussed or researched, demonstrating that computational tools' whole potential needs further study ${ }^{(5-6)}$.

Educational assessment in Brazil, however, is an expanding area, being considered a practice which permits transparency in institutional activities, as much for university communities as for society in general. There is, therefore, a growing interest in systematizing the evaluation of undergraduate and postgraduate courses, so as to enable socially sustained training, as well as to establish monitoring of policies directed at higher education(7).

Seen in these terms, two models of training assessment deserve to be singled out: the Integrated Somatic Model (MAIS, in Portuguese) which deals with environmental and process variables in the evaluation of training results, and the Evaluation of the Impact of Training at Work Model (IMPACT) which investigates diverse predictive variables for the efficiency and efficacy of training, analyzing the relationship between the levels of reaction, learning and impact(8-10).

The Impact model highlights the importance of knowing various demographic, motivational, cognitive and functional variables for the participants in the educational process, as it considers them to be predictors for the educational process ${ }^{(11)}$. The MAIS model, on the other hand, considers that knowledge gained from variables relating to the students makes it possible to select more effective educational events ${ }^{(12)}$.

In this context, the individual characteristics of the students doing distance courses over the Internet take on a particular importance, as this is a form of learning which depends much more on the effort of the individual him- or herself (self-management) than on the resources per se ${ }^{(9)}$. Thus, understanding the study habits and the learning strategies utilized in hybrid courses acquires relevancy.

Study habits are defined as procedures which integrate the best contextual aspects of the study environment and ways of studying with the acquisition and retention of learning, and include: the use of the library, managing study time and reading habits ${ }^{(13)}$.

Learning strategies are procedures (cognitive and behavioral abilities) utilized by individuals during learning activities so as to guarantee the success of all its stages. They are procedures focussed purely on learning activities. The strategies may be modified by the student with the goal of increasing learning's effectiveness in a specific activity or environment. This means that it is not that there are better strategies and worse strategies, but rather that there are strategies which are more or less suited to the type of activity to be learnt ${ }^{(14)}$.

In relation to the learning strategies of students involved in the process of distance learning, it may be said that they use strategies which are different from those used in courses where students have to be physically present, due to the new instructional procedures specific to web-based training. Therefore, studies of learning strategies can be useful to help the instructional planning of distance courses, by determining the strategies most used by the individuals, as well as by analyzing to which people determined procedures offered are best suited ${ }^{(9)}$.

In light of the above, with the aim of understanding important characteristics related to the students in Distance Learning (DL) and whether these differ according to academic level, the present research analyzed the study habits and learning strategies of undergraduates and postgraduates matriculated in hybrid courses in the health area, which use digital portfolios as pedagogic space.

\section{Method}

This is an exploratory study, using quantitative data collected in the period of January to February 2011.

The research was undertaken in the graduate courses Health Promotion 2 (HP2), Advanced Topics in Health Promotion 1 (ATHP), Health Research Methodology (HRM), in modules I, II and II of the Specialization in Health Education and Promotion course (SHEP) and in the Educative Practices in Health Sciences course (EPHS) offered by the Post-Graduate Nursing program in the Faculty 
of Health Sciences at the University of Brasília (UnB) and administered under the coordination of NESPROM.

The study was submitted to the Research Ethics Committee of the UnB's Faculty of Health Sciences and approved in December 2010, under protocol 137/10, based in Resolution 196/96 of the National Health Council, which deals with the regulatory guidelines and norms for research involving human beings.

The following inclusion criteria were utilized in the sample: all the students in undergraduate, specialization, master's or doctorate courses, of both sexes, duly matriculated, who concluded the courses or modules of the evaluated course in the second semester of 2010 and who accepted voluntarily to participate in the research, following signing of the Terms of Free and Informed Consent. Refusal to participate in the research was a criteria for exclusion.

Primary data was collected through a questionnaire made available in the virtual environment of the discipline or course evaluated. The instrument was adapted based on previous pieces of research(8,14-15), which utilized in their elaboration the theoretical models MAIS and IMPACT, made up of two stages, with the ultimate aim of collecting socio-demographic data (stage 1) and investigating the participating students' study habits and learning strategies (stage 2). The investigation of learning strategies utilized a scale constituted of 31 items, of the Likert type, of 11 points, varying from 0 (never) to 10 (always).

The disciplines ATHP, HRM and HP2 had, respectively, $44.34 \%, 84.62 \%$ and $95.65 \%$ of their students sampled, which represents $56.34 \%$ (80) of the total of graduates finishing their courses. In the post-graduate SHEP course and in the EPHS course, $68 \%$ and $96.23 \%$ of the students finishing their courses participated in the research, representing $87.18 \%$ of the total of post-graduate students. Thus, the sample of the present research was made up of 148 (67.27\%) of the 220 students approaching the ends of their courses.

The study applied quantitative data analysis to the students' personal data (age, sex, level of schooling etc) and to the participants' numerical responses to the questionnaires. The socio-demographic data, the study habits and the students' responses on the scale were submitted to exploratory, descriptive and analytical statistical analysis, including: median, average; standard deviation; percentages; presence of univariate extreme data; characteristics of frequency distributions; and analysis of difference between averages.

The responses to the 31 items relative to the scale which investigated the learning strategies, when submitted to the exploratory investigation, identified and excluded
37 univariate extreme cases (values for score $Z$ equal or superior to -3.29 or +3.29 ). The difference between the averages was analyzed by means of the non-parametric Mann-Whitney test, after confirming the non-normality of frequency distributions in both academic levels through the Kolmogorov-Smirnov test.

The Statistical Package for Social Sciences SPSS $₫$ version 17.0 was used for statistical analysis.

\section{Results}

\section{Characteristics of the participants}

In relation to the socio-demographic characterization, it stands out that the sample studied was made up predominantly of (75\%) female students, 56 (70\%) of whom came from groups composed of undergraduates (GRA) and 55 (80.9\%) from postgraduates (PG); members of both groups were predominantly single, although 28 $(41.2 \%)$ of the post-graduates and just $12(15 \%)$ of the undergraduates lived with a partner, which represented a significant difference $(p=0.001)$; as for the age of those involved, a difference may be observed between the undergraduates and the postgraduates $(p=0.001)$, the age range 18 to 23 years predominating in the GRA group (64 $-80 \%$ ), and the age range of the PG group ranging from 24 to 34 years of age ( $34-50 \%$ ). No differences were observed between the GRA and PG groups in the following variables: family income and computer ownership, with family income of over 8 minimum salaries in $99(66.9 \%)$ of the students and ownership of a computer in 146 $(98.6 \%)$ of the students.

\section{Study habits}

Table 1 presents the sample's study habits, discriminating between characteristics such as the amount of study hours per week (on and off the Internet), preferred times for studying, way of studying and reading of course content. It analyzes habits according to the students' academic level, seeking to identify possible differences.

\section{Learning Strategies}

The responses of the 148 students to the 31 items in the questionnaire which evaluated the learning strategies were divided in tables 2 and 3, which describe average and standard deviation (SD) of the total responses and according to academic level (GRA and PG), besides analyzing the difference between the averages of the undergraduates and postgraduates. 
Table 1 - Description of the study habits of the total of the students sampled, and according to academic level

\begin{tabular}{|c|c|c|c|c|c|c|c|}
\hline \multirow{2}{*}{ Variables } & \multicolumn{2}{|c|}{$\begin{array}{c}\text { Total } \\
\mathrm{n}=142\end{array}$} & \multicolumn{2}{|c|}{$\begin{array}{l}\text { GRA } \\
\mathrm{n}=72\end{array}$} & \multicolumn{2}{|c|}{$\begin{array}{c}P G \\
n=68\end{array}$} & \multirow[t]{2}{*}{$\mathbf{p}$} \\
\hline & $f$ & $\%$ & f & $\%$ & $f$ & $\%$ & \\
\hline Number of hours per week of study on the Internet & & & & & & & $0.001^{*}$ \\
\hline 0 to 1 & 12 & 8.1 & 11 & 14.9 & 1 & 1.5 & \\
\hline 1 to 2 & 35 & 23.6 & 26 & 35.1 & 9 & 13 & \\
\hline 2 to 3 & 58 & 39.2 & 31 & 41.9 & 27 & 40 & \\
\hline 4 to 5 & 23 & 15.5 & 5 & 6.76 & 18 & 26 & \\
\hline Over 5 & 14 & 9.5 & 1 & 1.35 & 13 & 19 & \\
\hline Number of hours of study per week off the Internet & & & & & & & $0.001^{*}$ \\
\hline 0 to 1 & 64 & 43.2 & 50 & 67.6 & 14 & 21 & \\
\hline 1 to 2 & 36 & 24.3 & 14 & 18.9 & 22 & 32 & \\
\hline 2 to 3 & 25 & 16.9 & 8 & 10.8 & 17 & 25 & \\
\hline 4 to 5 & 9 & 6.1 & 2 & 2.7 & 7 & 10 & \\
\hline Over 5 & 8 & 5.4 & 0 & 0 & 8 & 12 & \\
\hline Time preferred to study & & & & & & & $0.053^{*}$ \\
\hline Between midnight and six a.m & 15 & 10.1 & 6 & 8.11 & 9 & 13 & \\
\hline Between mid-day and six p.m & 18 & 12.2 & 13 & 17.6 & 5 & 7.4 & \\
\hline Between six a.m and mid-day & 17 & 11.5 & 8 & 10.8 & 9 & 13 & \\
\hline Between six p.m and midnight & 92 & 62.2 & 47 & 63.5 & 45 & 66 & \\
\hline Prefer to study & & & & & & & $0.033^{*}$ \\
\hline In a pair & 11 & 7.4 & 6 & 8.11 & 5 & 7.4 & \\
\hline In a group & 7 & 4.7 & 6 & 8.11 & 1 & 1.5 & \\
\hline Alone & 124 & 83.8 & 62 & 83.8 & 62 & 91 & \\
\hline Reading course content & & & & & & & $0.114^{*}$ \\
\hline Less than half & 3 & 2.0 & 2 & 2.7 & 1 & 1.5 & \\
\hline Half & 12 & 8.1 & 8 & 10.8 & 4 & 5.9 & \\
\hline More than half & 78 & 52.7 & 37 & 50 & 41 & 60 & \\
\hline All & 49 & 33.1 & 27 & 36.5 & 22 & 32 & \\
\hline
\end{tabular}

${ }^{*}$ Chi-squared test (calculated from the groups GRA and PG).

Table 2 - Learning Strategy: emotional control, interpersonal help and motivation

\begin{tabular}{|c|c|c|c|c|c|}
\hline $\mathbf{Q}^{*}$ & Variable & $\begin{array}{c}\text { Total } \\
\mathrm{N}=148 \\
\text { Average } \pm \mathrm{SD}\end{array}$ & $\begin{array}{c}\text { GRA } \\
\mathrm{N}=80 \\
\text { Average } \pm \mathrm{SD}\end{array}$ & $\begin{array}{c}\mathrm{PG} \\
\mathrm{N}=60 \\
\text { Average } \pm \mathrm{SD}\end{array}$ & p \\
\hline 1 & $\begin{array}{l}\text { I kept calm, faced with the possibility of things getting } \\
\text { difficult }\end{array}$ & $8.00 \pm 2,03$ & $8.17 \pm 1.82$ & $7.82 \pm 2.23$ & $0.561^{\dagger}$ \\
\hline 2 & $\begin{array}{l}\text { I repeated to myself that everything would turn out okay } \\
\text { at the end of the course }\end{array}$ & $8.54 \pm 1.61$ & $8.45 \pm 1.56$ & $8.63 \pm 1.66$ & $0.286^{\dagger}$ \\
\hline 3 & $\begin{array}{l}\text { I kept calm faced with the possibility of getting a lower } \\
\text { course grade than I expected }\end{array}$ & $7.23 \pm 2.76$ & $7.49 \pm 2.53$ & $6.96 \pm 2.98$ & $0.327^{\dagger}$ \\
\hline 4 & $\begin{array}{l}\text { I kept calm faced with the possibility of making mistakes } \\
\text { when carrying out course activities }\end{array}$ & $7.82 \pm 2.08$ & $7.99 \pm 2.04$ & $7.65 \pm 2.13$ & $0.279^{\dagger}$ \\
\hline 5 & I kept calm faced with the possibility of things going wrong & $7.62 \pm 2.18$ & $7.63 \pm 2.20$ & $7.62 \pm 2.17$ & $0.917^{\dagger}$ \\
\hline 6 & I expressed my ideas in forums for debate & $8.32 \pm 1.61$ & $8.06 \pm 1.75$ & $8.60 \pm 1.40$ & $0.076^{\dagger}$ \\
\hline 7 & I exchanged electronic messages with my colleagues & $6.38 \pm 3.08$ & $6.61 \pm 2.99$ & $6.13 \pm 3.17$ & $0.325^{\dagger}$ \\
\hline 8 & $\begin{array}{l}\text { I exchanged information with colleagues about } \\
\text { course content }\end{array}$ & $7.09 \pm 2.82$ & $7.32 \pm 2.60$ & $6.84 \pm 3.05$ & $0.473^{\dagger}$ \\
\hline 9 & I exchanged information with tutors about course content & $6.38 \pm 3.09$ & $5.65 \pm 3.20$ & $7.18 \pm 2.79$ & $0.001^{\dagger}$ \\
\hline 10 & I sought the help of tutors to clarify my doubts about content & $6.99 \pm 3.02$ & $6.36 \pm 3.26$ & $7.68 \pm 2.59$ & $0.004^{\dagger}$ \\
\hline 11 & I participated in forums as an observer & $7.54 \pm 2.78$ & $7.85 \pm 2.32$ & $7.19 \pm 3.19$ & $0.506^{\dagger}$ \\
\hline 12 & I forced myself to pay attention when I felt tired & $8.45 \pm 1.48$ & $8.22 \pm 1.52$ & $8.71 \pm 1.40$ & $0.036^{\dagger}$ \\
\hline 13 & $\begin{array}{l}\text { I made more effort when I noticed I was losing } \\
\text { concentration }\end{array}$ & $8.47 \pm 1.61$ & $8.29 \pm 1.61$ & $8.67 \pm 1.60$ & $0.080^{\dagger}$ \\
\hline 14 & I increased my efforts when the subject did not interest me & $7.95 \pm 2.06$ & $7.75 \pm 2.00$ & $8.16 \pm 2.11$ & $0.077^{*}$ \\
\hline
\end{tabular}

sQI: Questionnaire items: Learning Strategies Scale; *value of $\mathrm{p}$ calculated by the Mann-Whitney test, based on the difference between averages shown by groups GRA and PG. 
Table 3 - Learning Strategy: search, participation, repetition, organization and elaboration

\begin{tabular}{|c|c|c|c|c|c|}
\hline $\mathbf{Q}^{*}$ & Variable & $\begin{array}{c}\text { TOTAL } \\
\mathrm{N}=148 \\
\text { Average } \pm \text { SD }\end{array}$ & $\begin{array}{c}\text { GRA } \\
\mathrm{N}=80 \\
\text { Average } \pm \mathrm{SD}\end{array}$ & $\begin{array}{c}\mathrm{PG} \\
\mathrm{N}=60 \\
\text { Average } \pm \mathrm{SD}\end{array}$ & p \\
\hline 15 & I looked for other sites related to the discipline & $7.37 \pm 2.46$ & $7.11 \pm 2.51$ & $7.65 \pm 2.39$ & $0.174^{\dagger}$ \\
\hline 16 & $\begin{array}{l}\text { I looked for other research sources, apart from the Internet, } \\
\text { related to the discipline }\end{array}$ & $6.30 \pm 3.22$ & $6.27 \pm 3.17$ & $6.32 \pm 3.31$ & $0.797^{\dagger}$ \\
\hline 17 & $\begin{array}{l}\text { I read the notices and news divulged in the course } \\
\text { environment }\end{array}$ & $8.89 \pm 1.42$ & $8.78 \pm 1.61$ & $9.01 \pm 1.18$ & $0.703^{\dagger}$ \\
\hline 18 & $\begin{array}{l}\text { I participated in physical meetings pre-arranged on the } \\
\text { course with colleagues, tutors, etc. }\end{array}$ & $8.60 \pm 1.82$ & $8.57 \pm 1.99$ & $8.64 \pm 1.65$ & $0.828^{+}$ \\
\hline 19 & $\begin{array}{l}\text { I participated in non-pre-arranged physical meetings on the } \\
\text { course with colleagues. }\end{array}$ & $4.58 \pm 4.24$ & $4.88 \pm 4.14$ & $4.25 \pm 4.35$ & $0.364^{\dagger}$ \\
\hline 20 & $\begin{array}{l}\text { I participated in non-pre-arranged physical meetings on the } \\
\text { course with tutors. }\end{array}$ & $4.32 \pm 4.09$ & $4.24 \pm 4.01$ & $4.40 \pm 4.20$ & $0.884^{\dagger}$ \\
\hline 21 & I carried out the proposed activities just within deadlines & $8.34 \pm 1.72$ & $8.36 \pm 1.80$ & $8.32 \pm 1.64$ & $0.698^{+}$ \\
\hline 22 & $\begin{array}{l}\text { I revised the content relative to exercises in which I made } \\
\text { mistakes }\end{array}$ & $7.46 \pm 2.54$ & $7.00 \pm 2.91$ & $7.96 \pm 1.97$ & $0.094^{\dagger}$ \\
\hline 23 & I made notes about course content & $7.16 \pm 2.78$ & $6.53 \pm 3.03$ & $7.85 \pm 2.31$ & $0.008^{+}$ \\
\hline 24 & I mentally repeated course content & $7.13 \pm 2.75$ & $6.91 \pm 2.91$ & $7.38 \pm 2.55$ & 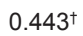 \\
\hline 25 & I drew diagrams to study course content & $5.73 \pm 3.48$ & $5.34 \pm 3.44$ & $6.16 \pm 3.48$ & $0.097^{\dagger}$ \\
\hline 26 & I made a summary of the course content & $6.32 \pm 3.32$ & $6.32 \pm 3.23$ & $6.31 \pm 3.43$ & $0.740^{\dagger}$ \\
\hline 27 & I read the course contents on the screen of the computer & $8.81 \pm 1.48$ & $8.84 \pm 1.53$ & $8.77 \pm 1.44$ & $0.582^{\dagger}$ \\
\hline 28 & I read the course content from material which I printed off & $5.22 \pm 4.03$ & $4.73 \pm 4.09$ & $5.75 \pm 3.93$ & $0.130^{\dagger}$ \\
\hline 29 & I associated course content to my pre-existing knowledge & $8.51 \pm 1.52$ & $8.43 \pm 1.52$ & $8.60 \pm 1.54$ & $0.441^{\dagger}$ \\
\hline 30 & I associated course content with my previous experiences & $8.60 \pm 1.47$ & $8.38 \pm 1.60$ & $8.84 \pm 1.28$ & 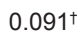 \\
\hline 31 & $\begin{array}{l}\text { I identified situations where I could apply course content in } \\
\text { my day-to-day }\end{array}$ & $8.33 \pm 1.75$ & $8.24 \pm 1.71$ & $8.43 \pm 1.80$ & $0.361^{\dagger}$ \\
\hline
\end{tabular}

*IQ= Questionnaire items: Learning Strategies Scale; ${ }^{+}$value of $\mathrm{p}$ calculated by the Mann-Whitney test, based on the difference between averages presented by the groups GRA and PG.

\section{Discussion}

\section{Participants' characteristics}

Higher frequencies may be observed, therefore, in both groups, of female students, of young people in the age range of 18 to 34 years, of people who possess a computer and who have a family income of over 8 minimum salaries.

The gender tendency identified above aligns with the profile of university students presented in a study ${ }^{(16)}$ which, in analyzing the inclusion of women in higher education in Brazil, affirmed that the proportion of women (55.8\%) was higher than that of men $(44.2 \%)$ in higher education in Brazil. Studies carried out with university students in hybrid courses have identified similar tendencies for gender and age ranges ${ }^{(15)}$.

\section{Study habits}

Table 1 shows the similarity in education habits between undergraduates and postgraduates, emphasizing the preferences, which are: study time comprising the period between six p.m and midnight, and studying alone, besides both groups having read more than half of the course content. The fact that postgraduate students study more than undergraduates, on and off the Internet, constitutes the principal difference identified.

\section{Learning Strategy}

The 31 items described in Tables 2 and 3 had the following proportions: averages equal or superior to 7 were identified in 22 items (71\%) when all the students were considered, in 20 items (64\%) when only GRA students were considered, and in 22 items (71\%) when only PG students were considered; averages greater than or equal to 5 and lower than 7 were identified in 7 items $(22.6 \%)$ when all students were considered, in 8 items $(25.8 \%)$ when undergraduates were considered and in 7 (22.6\%) when only postgraduate students were considered; averages lower than 5 were identified in just 2 items (6.4\%) when all students were considered, in 3 items $(9.7 \%)$ in the GRA and in 2 items $(6.4 \%)$ in the PG. The SD showed the least value in item 17 (1.42) and the greatest value in item 19 (4.24) when data from all students were considered, in items 12 (1.52) and 19 (4.14), when only the GRA group was considered and in the items 17 (1.18) and 19 (4.35), when considering only the postgraduates. Thus some items had high standard deviation values, indicating a spread in the responses from both groups. 
Studies ${ }^{(8,15,17)}$ which utilized instruments similar to those adopted in the present research to evaluate learning strategies among distance-learning students, presented respectively averages over 7 in $48 \%, 52 \%$ and $47 \%$ of the participants, demonstrating that the values identified in both the groups researched indicate high use of learning strategies among undergraduates and postgraduates.

The most-utilized study strategies were reading notices and news posted in the course environment, followed by the strategies: I read the course content on the computer screen, participated in physical prearranged course meetings with colleagues and tutors and $I$ associated the course content with my previous experiences. On the other hand, the least-used learning strategies were: I participated in physical non-prearranged course meetings with tutors and I participated in physical non-pre-arranged course meetings with colleagues.

No significant differences $(p<0,05)$ were found between non-parametric averages of graduate and postgraduate students in 27 items of the scale evaluated. Statistically significant differences were observed only in items 9, 10, 12 and 23.

Item 9, I exchanged information with tutors about course content, presented $\mathrm{p}=0,001$ and a difference between averages which indicates a medium effect $(\mathrm{d}=0,51)$; item 10, I sought help from the tutors to clarify my doubts about the content, presented $\mathrm{p}=0,004$ and a difference between averages indicating a small effect $(\mathrm{d}=0,45)$; item $12, I$ made notes about course content, with a value of $p=0,008$ and a difference between averages indicating a small effect $(\mathrm{d}=0,49)$ and item 23, I forced myself to pay attention when I felt tired, with $\mathrm{p}=0,036$, with a difference between averages showing a small effect $(d=0,33)$. Thus, it can be seen that in 27 items there were no significant differences, and in 4 items the differences were significant, although the differences in three were small and in one moderate, indicating therefore a similarity in the use of learning strategies among undergraduates and postgraduates.

\section{Conclusion}

The investigation of study habits indicates that postgraduate students spend more hours per week studying, both on and off the Internet, although there was a predominance of 2 to 3 hours of Internet study in both groups. The students of both groups read more than half or all the course content and indicated a preference for studying alone and in the period between six in the evening and midnight.
The learning strategies used by the students were evaluated by 31 items. The students from both academic levels utilized the majority of the strategies appropriately (averages over 7). Only two strategies were little-used (averages of 4 or below) by the students, these being: $I$ participated in physical non-pre-arranged course meetings with colleagues and I participated in physical non-prearranged meetings with tutors, which indicates that possibly there is no incentive for unarranged meetings in conducting the disciplines.

It is verified that there was no difference as to the utilization of the majority of strategies by undergraduates and postgraduates. Moderate differences were observed only in the variable $I$ exchanged information with tutors about course content, besides small differences in the variables: I sought help from the tutors to clarify my doubts about the content, I made notes about course content and I forced myself to pay attention when I felt tired.

Concerning the study's limitations, the following may be highlighted: the non-utilization of qualitative data collection strategies, which might have made it possible to widen understanding of the characteristics studied, and the limitation concerning generalization of the results, resulting from the peculiarities inherent to the characteristics of the students and the methodology utilized in the disciplines.

\section{References}

1. Saraiva LM, Pernigotti JM, Barcia RM, Lapolli EM. Tensions that affect distance learning settings. Psicol Estudo. 2006;11(3):483-91.

2. Barbosa SFF, Marin HF. Web-based simulation: a tool for teaching critical care nursing. Rev. Latino-Am. Enfermagem. 2009;17(1):7-13.

3. Rangel EML, Mendes IAC, Cárnio EC, Alves LMM, Crispim JA, Mazzo A, et al. Evaluation by nursing students in virtual learning environments for teaching endocrine physiology. Acta Paul Enferm. 2011;24(3):327-33.

4. Paiva VMO. Virtual learning environments: epistemological implications. Educ Rev. 2010;26(3):353-70.

5. Camacho ACLF. Analysis of national publications about distance education in nursing. Rev Bras Enferm. 2009;62(4):588-93.

6. Silva APSS, Pedro ENR. Autonomy in Nursing Students' Process of Knowledge Construction: the Educational Chat as a Teaching Tool. Rev. Latino-Am. Enfermagem. 2010;18(2):210-6.

7. MEIRA MDD; KURCGANT, P. College program evaluation according to graduate. Rev Esc Enferm USP. 2009;43(2):481-5. 
8. Zerbini T. Avaliação da transferência de treinamento em curso a distância [tese de doutorado]. Brasília (DF): Instituto de Psicologia da Universidade de Brasília; 2007. 321 p.

9. Zerbini T, Abbad G. Impact of training on the job through the Internet. Rev Admin Empresas. 2005;4(2):0-0.

10. Zerbini T, Abbad G. Qualificação profissional a distância: ambiente de estudo e procedimentos de interação validação de uma escala. Análise. 2008;19(1):148-72.

11. Abbad G. Um modelo integrado de avaliação do impacto do treinamento no trabalho - IMPACT [tese de doutorado]. Brasília (DF): Instituto de Psicologia da Universidade de Brasília; 1999. 289 p.

12. Borges-Andrade JE. Avaliação integrada e somativa em TD\&E. In: Borges-Andrade JE, Abbad G, Mourão L, organizadores. Treinamento, desenvolvimento e educação em organizações e trabalho: fundamentos para a gestão de pessoas. Porto Alegre (RS): Artmed; 2006. p. 343-58. 13. Warr $P$, Allan $C$. Learning strategies and occupational training. Int Rev Ind Org Psychol. 1998;13(1):83-121.

14. Zerbini T, Abbad G. E Learning strategies in distance course: Validation of a scale. Psico-USF. 2008;13(2):177-87. 15. De Paula e Silva A. Avaliação de uma disciplina semipresencial de graduação ofertada por meio da Internet na Universidade de Brasília [dissertação de mestrado]. Brasília (DF): Instituto de Psicologia da Universidade de Brasília; 2004. 173 p.

16. Osório FL, Crippa JAS, Loureiro SR. Escala para auto-avaliação ao falar em público (SSPS): adaptação transcultural e consistência interna da versão brasileira. Rev Psiquiatr Clín. 2008;35(6):207-11.

17. Correa VP. Avaliação de Treinamento a Distância em uma Organização Pública [dissertação de mestrado]. Brasília (DF): Instituto de Psicologia da Universidade de Brasília; 2007. 172 p. 